\title{
PERAN KEPEMIMPINAN KEPALA MADRAsaH dalaM MENGEMBANGKAN BUdAYA MEMBACA AL-QUR'AN DI madrasaH tsanaWIYAH NEGERI I PALEmbang
}

\author{
Ermanati
}

\author{
Program Pascasarjana \\ Universitas Islam Negeri Raden Fatah Palembang \\ E-mail:ermawati_uin@radenfatah.ac.id
}

\begin{abstract}
This background of the effort to improve the learning process of the Qur'an is necessary because the Qur'an is the source of the law and the main rule for Muslims and grace performed MTs N 1 Palembang. The purpose of this research is to know and understand the role of leadership of madrasah head in developing the culture of reading al-Qur'an in MTs Negeri 1 Palembang and the impact of leadership role of madrasah head in developing the culture of reading al-Qur'an in MTs Negeri 1 Palembang. The research results obtained the following results: The role of leadership of madrasah head in developing the culture of reading the Qur'an in MTs Negeri 1 Palembang seen in the ability to coordinate the activities tahfidz al-Qur'an, in terms of problem solving in the program of culture al-Qur 'An, he gave authority to the concerned to solve it. The principal establishes communication with good language especially on issues in which the cultural activities of reading the Qur'an are concerned. The principal has given good motivation to the participants tahfidz the teacher in charge, both in the form of praise, trust and physical form. The impact of the leadership role of madrasah head in developing the culture of reading al-Qur'an in MTs Negeri 1 Palembang make the program of reading al-Qur'an culture focused on the activities of tahfidz al-Qur'an in MTs N 1 Palembang run effectively proven by many students Already memorized 1 juz even have 5 and 7 juz.
\end{abstract}

Keywords: Principal, Culture reading al-Qur'an, MTs N 1 Palembang

\footnotetext{
Abstrak

Hal ini dilatar belakangi oleh Usaha untuk meningkatkan proses pembelajaran al-Qur'an sangat diperlukan karena al-Qur'an merupakan sumber hukum dan aturan yang utama bagi umat Islam dan rahmat yang dilakukan MTs N 1 Palembang. Tujuan penelitian ini adalah mengetahui dan memahami peran kepempimpinan
}

kepala madrasah dalam mengembangkan budaya membaca al-Qur'an di MTs Negeri 1 Palembangdan dampak peran kepempimpinan kepala madrasah dalam mengembangkan budaya membaca al-Qur'an di MTs Negeri 1 Palembang. Adapun hasil penelitian diperoleh hasil sebagai berikut: Peran kepempimpinan kepala madrasah dalam mengembangkan budaya membaca al-Qur'an di MTs Negeri 1 Palembang terlihat pada Kemampuan melakukan koordinasi pada kegiatan tahfidz al-Qur'an, dalam hal penyelesaian masalah dalam program budaya al-Qur'an, beliau memberikan wewenang kepada yang bersangkutan untuk menyelesaikannya. Kepala sekolah membangun komunikasi dengan bahasa yang baik terutama pada masalah dalam yang menyangkut kegiatan budaya membaca al-Qur'an. Kepala sekolah telah memberikan motivasi baik pada peserta tahfidz mauapun guru yang bertugas, baik berbentuk pujian, kepercayaan dan berbentuk fisik. Dampak peran kepempimpinan kepala madrasah dalam mengembangkan budaya membaca al-Qur'an di MTs Negeri 1 Palembang menjadikan program budaya membaca al-Qur'an yang terfokus pada kegiatan tahfidz al-Qur'an di MTs N 1 Palembang berjalan efektif terbukti dengan banyak siswa yang sudah hafal 1 juz bahkan ada yang 5 dan 7 juz.

Kata kunci: Kepala Sekolah, Budaya membaca alQur'an, MTs N 1 Palembang

Dalam pelaksanaannya untuk menciptakan suasana yang efektif dalam lambaga pendidikan di perlukan seorang pemimpin yang baik dalam hal ini adalah kepala sekolah/madrasah. Dalam perspektif kebijakan pendidikan nasional, terdapat tujuh peran Kepala Madrasah (EMASLIM) yaitu, sebagai: (1) educator (pendidik); (2) manajer; (3) administrator; (4) supervisor; (5) leader (pemimpin); (6) inovator; dan (7) motivator (Sumidjo, 2002: 83). Dari ketujuh peran kepala 


\section{Haril Penelitian}

sekolah di atas, yang akan di bahas adalah peran kepala sekolah sebagai manager dan administrator dalam lembaga pendidikan.

Madrasah merupakan salah satu lembaga pendidikan Islam formal yang ada di Indonesia. Mengingat lembaga pendidikan ini adalah lembaga pendidikan Islam, sudah tentu nilai utama yang menjadi dasar adalah nilai-nilai al-Qur'an. Pada kenyataannya Madrasah saat ini sudah mulai terbawa arus modernisasi dan pengaruh paradigma pendidikan modern yang mendahulukan IPTEK di atas segalannya. Sehingga sedikit demi sedikit dapat dirasakan bahwa madrasah tidak lagi menjadi lembaga yang memproduksi ahli-ahli al-Qur'an dan hal ini sudah terasa disemua aspek yang ada dalam madrasah itu sendiri. Contoh aspek tersebut adalah Sumber Daya Manusia (SDM) mulai dari tenaga pendidik sampai tenaga kependidikan dan aktor penting dalam hal ini adalah Kepala Madrasah.

Dewasa ini seiring dengan berkembangnya Sistem Pendidikan Nasional, diikuti juga dengan semakin maju proses yang terjadi dalam pendidikan itu sendiri, hal ini tentu saja melibatkan banyak komponen misalnya Kepala Madrasah. Berkenaan dengan konsep keberhasilan proses pembelajaran orientasi yang selama ini terjadi hanya berfokus pada pencapaian kurikulum normatif saja yakni kurikulum yang telah disediakan oleh pemerintah. Padahal dibalik hal itu sebenarnya yang tidak kalah pentingnya adalah konsep dari Madrasah itu sendiri yaitu sebagai wadah pendidikan Islam atau biasa disebut dengan lembaga pendidikan Islam. Meskipun demikian pada kenyataannya banyak sekolah umum yang prestasi dalam bidang keagamaannya lebih baik dibandingkan dengan Madrasah itu sendiri, misalnya dalam proses pembelajaran al-Qur'an. Pada dasarnya orang yang paling bertanggung jawab dalam hal ini adalah Kepala Madrasah. Dalam hal ini tentu saja kompetensi Kepala Madrasah yang baik pula diperlukan guna mengembalikan paradigma Madrasah sebagai lembaga pendidikan Ilmu AlQur'an.

Menurut Effendi dalam buku E. Mulyasa "Menjadi Kepala Madrasah Profesional" bahwa: "pengembangan sumber daya manusia termasuk di dalamnya adalah peningkatan partisipasi manusia melalui perluasan kesempatan untuk mendapatkan penghasilan, peluang kerja, dan usaha (Mulyasa, 2004: 24).”

Proses pengembangan SDM tersebut harus menyentuh berbagai bidang kehidupan yang harus tercermin dalam pribadi para pemimpin, termasuk para pemimpin pendidikan, seperti Kepala Madrasah. Oleh karena itu, peningkatan kualitas SDM, lebih-lebih Kepala Madrasah sebagai pemimpin pendidikan di sekolah merupakan suatu tuntutan untuk meningkatkan kualitas pendidikan dalam konteks otonomi daerah dan desentralisasi pendidikan.

Paradigma pendidikan yang memberikan kewenangan luas Kepala Madrasah dalam mengembangkan berbagai potensinya memerlukan peningkatan kemampuan Kepala Madrasah dalam berbagai aspek manajerialnya, agar dapat mencapai tujuan sesuai dengan visi dan misi yang diemban oleh sekolahnya. Sebagai ilustrasi dapat dikemukakan misalnya, Kepala Madrasah dituntut untuk memiliki kemampuan melakukan pengelolaan keuangan dengan sebaikbaiknya di sekolah.

Kepala Madrasah merupakan salah satu komponen tenaga kependidikan yang paling berperan dalam meningkatkan kualitas pendidikan. Erat hubungannya antara mutu Kepala Madrasah dengan berbagai aspek kehidupan sekolah seperti disiplin sekolah, iklim budaya sekolah, dan menurunnya perilaku nakal peserta didik.

Dari pada itu, Kepala Madrasah bertanggung jawab atas manajemen pendidikan secara mikro, yang secara langsung berkaitan dengan proses pembelajaran di sekolah. Sebagaimana dikemukakan dalam Pasal 12 ayat 1 PP 28 tahun 1990 bahwa: "Kepala Madrasah bertanggung jawab atas penyelenggaraan kegiatan pendidikan, administrasi sekolah, pembinaan tenaga kependidikan lainnya, dan pendayagunaan serta pemeliharaan sarana dan prasarana (Mulyasa, 2004: 28)."

Apa yang diungkapkan di atas menjadi lebih penting sejalan dengan semakin kompleksnya tuntutan tugas Kepala Madrasah, yang menghendaki dukungan kinerja yang semakin efektif dan efisien. Di samping itu, perkembangan ilmu pengetahuan, teknologi, seni, dan budaya yang diterapkan dalam pendidikan di sekolah 


\section{Hasil Penelitian}

juga cenderung bergerak maju semakin pesat, sehingga menuntut penguasaan secara profesional. Menyadari hal tersebut, setiap Kepala Madrasah dihadapkan pada tantangan untuk melaksanakan pengembangan pendidikan secara terarah, berencana, dan berkesinambungan untuk meningkatkan kualitas pendidikan. Oleh karena itu, untuk menunjang keberhasilan dalam perubahan-perubahan yang dilakukan dan diharapkan, perlu dipersiapkan Kepala Madrasah profesional, yang mau dan mampu melakukan perencanaan, pelaksanaan, serta evaluasi terhadap berbagai kebijakan dan perubahan yang dilakukan secara efektif dan efisien.

Berkenaan dengan konsep keberhasilan proses pembelajaran orientasi yang selama ini terjadi hanya berfokus pada pencapaian kurikulum normatif saja yakni kurikulum yang telah disediakan oleh pemerintah. Padahal dibalik hal itu sebenarnya yang tidak kalah pentingnya adalah konsep dari madrasah itu sendiri yaitu sebagai wadah pendidikan Islam atau biasa disebut dengan lembaga pendidikan Islam. Meskipun demikian pada kenyataannya banyak sekolah umum yang prestasi dalam bidang keagamaannya lebih baik dibandingkan dengan madrasah itu sendiri, misalnya dalam proses pembelajaran al-Qur'an. Pada dasarnya orang yang paling bertanggung jawab dalam hal ini adalah kepala madrasah. Dalam hal ini tentu saja kompetensi kepala madrasah yang baik pula diperlukan guna mengembalikan paradigma Madrasah sebagai lembaga pendidikan Ilmu al-Qur'an sekaligus sebagai lembaga pendidikan yang menjadi wadah budaya membaca al-Qur'an.

Oleh karena itu, peran Kepala Madrasah dan guru sangat diperlukan untuk mengatasi masalah masih banyaknya siswa MTs Negeri 1 Palembang dalam mengoptimalkan perannya dalam pelaksanaan budaya membaca al-Qur'an melalui program tahfidz al-Qur'an. Hal tersebut dapat diatasi oleh Kepala Madrasah dengan melakukan usaha-usaha yang dapat meningkatkan kemampuan membaca al-Qur'an siswa dan meningkatkan proses pembelajaran al-Qur'an.

Usaha untuk meningkatkan proses pembelajaran al-Qur'an sangat diperlukan karena al-Qur'an merupakan sumber hukum dan aturan yang utama bagi umat Islam dan rahmat yang tiada banding bagi kehidupan manusia karena di dalamnya terkumpul wahyu Ilahi yang menjadi petunjuk, pedoman, dan pelajaran bagi siapa saja yang mengimaninya. Sejalan dengan hal tersebut, al-Qur'an yang diwahyukan oleh Allah SWT kepada Rasulullah SAW tidak sekedar berfungsi sebagai perwujudan bukti kekuasaan Allah SWT semata. Di samping itu al-Qur'an juga mengandung nilai-nilai dan ajaran yang harus dilaksanakan oleh manusia. Oleh karena itu, bagi orang yang beriman, kecintaannya kepada alQur'an akan bertambah dan sebagai bukti cintanya, dia akan semakin bersemangat membacanya setiap waktu, mempelajari isi kandungannya dan memahaminya. Selanjutnya akan mengamalkan al-Qur'an dalam kehidupannya sehari-hari, baik dalam hubungannya dengan Allah SWT maupun dengan lingkungan sekitar.

\section{Metodologi Penelitian}

Ditinjau dari pendekatannya, penelitian ini adalah termasuk jenis penelitian kualitatif. Sebab, mencoba menguak data dalam bentuk pernyataan, simbolik, penafsiran, tanggapan lisan, dan sebagainya. Dari sisi metode termasuk jenis penelitian studi kasus. Ditinjau dari tempat penelitiannya, penelitian hanya dilakukan di laboratorium, perpustakaan dan penelitian lapangan (field research). Penelitian ini merupakan penelitian yang dilakukan di lapangan atau field research yakni MTs Negeri 1 Palembang. Berikut teknik pengumpulan data yang digunakan dalam penelitian ini: 1) Teknik interview/wawancara; 2) Teknik observasi; dan 3) Teknik dokumentasi.

Peran Kepempimpinan Kepala Madrasah dalam Mengembangkan Budaya Membaca al-Qur'an di MTs Negeri 1 Palembang

\section{Peran Kepempimpinan Kepala Madrasah Leader (pemimpin) \\ Berkenaan dengan pertanyaan "Sebagai} leader yang baik tentu perlu adanya koordinasi dalam segala hal, apakah kepala sekolah ini melakukan hal yang sama, khususnya dalam program tahfidz Qur'an?“‘

Narasumber AS mengatakan, "Sebagai seorang kepala sekolah bapak Yan Hery selalu bermusyawarah dengan wakil-wakilnya, guru 


\section{Haril Penelitian}

maupun staf, jika beliau memiliki suatu pemikiran guna kemajuan sekolah. Tidak secara langsung beliau realisasikan setiap idenya, karena beliau selalu menghargai bawahannya, agar pekerjaan terkoordinasi dengan baik (Asmiati, Wawancara; 5-9-2016)."

Sebagai kepala madrasah banyak peran yang akan bapak jalankan di antaranya adalah peran sebagai leader, menejer dan administrator, bagaimana bapak menjalankan peran yang dimaksud?

Tidak semua tugas di sekolah saya kerjakan sendiri, karena personel sekolah telah memiliki tugas masing-masing, sebagai contoh: urusan evaluasi belajar, intrakurikuler, begitu juga ketika akan mengutus guru berprestasi maka kepala sekolah memerintah bagian kurikulum untuk memutuskan. Urusan yang berkaitan dengan siswa berprestasi, siswa bermasalah, siswa miskin, ekstrakurikuler semua kembali pada bagian kesiswaan. Urusan inventaris barang, sarana prasarana dan pemeliharaannya, laboratorium serta belanja perpustakaan semua dikembalikan pada bagian sarana prasarana. Dan yang berkaitan dengan hubungan dengan orang tua, komite, dinas, dan hubungan dengan dunia usaha semua di bawah kepegawasan urusan humas. Serta masalah mata pelajaran pada guru masing-masing. Tetapi semua itu tidak serta merta hanya menjadi tanggung jawab mereka, saya juga mempunyai kewajiban untuk mengawasi, tutur narasumber YHD (Darmansyah, Wawancara; 5-9-2016).

Pernyataan tersebut selaras dengan hadits nabi Muhammad, Saw yang menjelaskan bahwa: "Jika amanat telah disia-siakan, tunggu saja kehancuran terjadi." Ada seorang sahabat bertanya; "Bagaimana maksud amanat disia-siakan?" Nabi menjawab, "Jika urusan diserahkan bukan kepada yang ahlinya, maka tunggulah kehancuran itu." (Bukhori-6015)

Semua pekerjaan haruslah didasarkan dengan keahlian dan pengetahuan yang dimiliki oleh seseorang, agar hasil yang diperoleh akan lebih optimal karena yang mengerjakannya benar-benar orang yang profesional dibidangnya. Sebagai misal guru mengaji haruslah yang bisa mengaji, mengerti tajwid, fasih bacaannya, bila perlu yang bagus suaranya. Begitu juga guru sosiologi harus yang memang benar-benar memiliki latar belakang pendidikan sosiologi. Karena merekalah yang lebih mengetahui tentang ilmu yang akan dibagikan, maka akan tidak amanah jika orang yang memiliki latar belakang pendidikan Bahasa Inggris dan ia mengajarkan ilmu agama Islam.

Narasumber HFW menjelaskan bahwa, "Pembagian kerja pada guru dan staf sudah sesuai dengan kemampuan yang dimiliki serta latar belakang pendidikan masing-masing. Akan tetapi ada seorang guru yang sebenarnya berlatar belakang komputer dan mengajar komputer di MTs Negeri 1 Palembang, tetapi mata pelajaran komputer dihapuskan sehingga guru tersebut mengajar masakan daerah, sehingga tidak sesuai dengan latar belakang pendidikannya, tetapi guru tersebut diberi kesempatan/difasilitasi oleh sekolah untuk mengembangkan ilmu tentang masda dan bapak kepala sekolah juga menyarankan untuk sharing dengan guru-guru yang lain yang mengajar madrasah" (Wazier, Wawancara; 5-9-2016).

Kejadian tersebut sungguh sangat disayangkan mengingat komputer sangat baik untuk dipelajari sebagai salah satu yang menunjang keberhasilan siswa mengingat dunia sekarang sudah semakin modern, sehingga semua dituntut untuk bisa bisa mengoperasikan komputer, apalagi yang menyangkut dunia kerja. Sebagai seorang guru tentu bsangat bermanfaat untuk membuat RPP, Silabus, Prota, Prosem. Begitu juga seorang Tata Usaha segala urusan sekolah harus didokumentasikan ke dalam komputer. Pekerja bank, sekretaris semua pekerjaan itu menuntut semua orang untuk tidak gagap teknologi (gaptek).

Dalam menghadapi konflik yang ada ketika melaksanakan suatu program, apa yang akan dilakukan kepala sekolah sebagai leader?

Narasumber HFW menjelaskan "Alhamdulillah di sekolah ini belum pernah terjadi konflik yang berkepanjangan baik antar guru, guru dengan orang tua siswa, guru dengan siswa, dengan staf atau bahkan kepala sekolah dengan guru dan lainnya. Karena jika konflik terjadi kepala sekolah langsung memerintahkan bawahan yang berUsman Salehan untuk menyelesaikannya. Jika ada pihak yang merasa kurang puas, maka diselesaikan secara langsung oleh bapak kepala sekolah", ujar ibu Fatmawati (Fatmawati, Wawancara; 5-9-2016). 


\section{Hasil Penelitian}

Seorang kepala sekolah dan guru haruslah menjadi teladan dan sungguh tidak patut jika terjadi konflik dalam waktu yang lama, apalagi sampai adu mulut, tarik-tarikan jilbab, hal itu sungguh memalukan dan di MTs Negeri 1 Palembang sejauh ini dalam pengamatan tidak pernah terjadi hal-hal yang tidak diinginkan. Mereka sungguh menjaga nama baik guru dan sekolah.

Pernahkan terjadi konflik dikalangan guru, langkah apa yang di ambil kepala sekolah dalam menyelesaikannya?

Nasumber FW menuturkan, "Selama masa bapak Yan Hery menjadi kepala sekolah, tidak pernah terjadi konflik antar guru, mungkin jika rasa saling tidak suka ada, tetapi kebanyakan guru disini sudah senior-senior sudah hampir pensiun, tentunya mereka sudah banyak sekali pengalaman, sehingga mereka bisa mengontrol emosi dan disebabkan karena rasa kekeluargaan yang kental.

Jika ada program yang belum optimal hasilnya, biasanya apa yang dilakukan oelh pegawai disini?

Bapak US menjelaskan bahwa, "Jika ada masalah kecil antar guru, langsung diselesaikan oleh yang bermasalah. Mereka saling menasehati sehingga membuat mereka saling instropeksi diri apakah ia memang benar atau bahkan salah. Itulah guna hidup bermasyarakat untuk saling mengajak kepada kebenaran dan mencegah pada kemunkaran sebagaimana dijelaskan dalam agama kita "Islam" (Saleh, Wawancara; 6-9-2016).

Pernahkan terjadi masalah dalam pengajaran di sekolah ini, bagaimana peran kepala sekolah dalam menyelesaikannya?

Lain halnya dengan Ibu IS, beliau mengatakan bahwa, "Pernah terjadi suatu kejadian di kelas, ada siswa yang dipindahkan kelasnya, tetapi seorang guru yang mengajar di kelas tempat ia pindah tidak mau menerima. Sudah dinasehati guru yang lain, tetap saja menolak siswa. Lalu guru yang tidak mau menerima dipanggil oleh bapak kepala sekolah untuk bertatap muka, kemudian diberi kesempatan untuk menjelaskan duduk masalahnya, diajak berdiskusi, diberi masukan. Bapak juga melalukan cross ceck dengan guru yang lain. Akhirnya sang guru mau menerima siswa tersebut (Suryani, Wawancara; 6-9-2016).”

Dari hasil wawancara dan observasi di atas menunjukkan bahwa bapak kepala sekolah sangat peka terhadap masalah yang dihadapi oleh bawahannya. Diselesaikan oleh yang bermasalah terlebih dahulu, jika tidak terselesaikan barulah bapak kepala sekolah langsung yang menanganinya, mendekati guru yang terlibat konflik dan menanyakan dengan guru yang lain apa permasalahannya dengan cara kekeluargaan. Konflik yang menyangkut siswa diserahkan kepada guru-guru yang mengajar, ketidakpahaman mengenai kurikulum dengan waka kurikulum, hubungan dengan masyarakat dengan waka humas, dan lain-lain sesuai prosesdur.

Dalam menejalankan peran manajer bagaimana kepala sekolah menyikapi etos kerja dan komunikasi kerja yang beragam dalam program tahfidz Qur'an disekolah ini?

Ibu HFW mengatakan bahwa, "Bapak kepala sekolah memiliki kepribadian yang sangat baik sebagai seorang pemimpin di lingkup sekolah, beliau berusaha menjadi teladan yang benar-benar patut diteladani dan bersahabat dengan bawahan, kepala sekolah memiliki ide-ide yang kreatif untuk membuat sekolah lebih baik" (Wazier, Wawancara; 5-9-2016).

Bapak kepala sekolah selalu berusaha untuk mencapai tujuan sekolah sebaik mungkin, jika dilihat dari segi lingkungan fisik sekolah menjadi lebih baik banyak sekali perubahan, yakni dari segi ruang kelas, WC, lingkungan sekolah yang sudah sangat menghijau sehingga lebih terasa sejuk dan nyaman. Semua tak terlepas dari kepribadian beliau yang memiliki jiwa kewirausahaan, inovatif, percaya diri dan mampu bekerja sama dengan bawahan-bawahannya. Tentunya kepribadian tersebut membuat kepemimpinan beliau sebagai kepala sekolah lebih efektif.

\section{Peran Kepempimpinan Kepala Madrasah Manajer}

Seorang kepala sekolah dapat mencapai tujuan sekolah tidak terlepas dari bantuan orang lain. Oleh sebab itu, setiap pemberian informasi, perintah atau permintaan harus dapat dimengerti dengan baik oleh orang lain. Seorang pemimpin harus dapat menyampaikan gagasannya kepada orang lain dengan jelas baik lewat tulisan, ucapan atau perbuatan. Sebagai contoh, program kerja kepala sekolah tidak dapat terealisasi tanpa diinformasikan terlebih dahulu dengan anggota 


\section{Hagil Penelition}

yang lain, dan sejauh ini program kerja kepala sekolah yang telah terealisasi selama 1,5 tahun masa jabatan di MTs Negeri 1 Palembang, yaitu sebagai berikut:

Ibu AS menjelaskan, "Beliau selalu mengkomunikasikan apapun yang menjadi program kerjanya, dan beliau selalu berkomunikasi pada guru-guru, tata usaha, apalagi ketika pagi-pagi beliau berdiri di depan dan menyapa semuanya, selamat pagi, apa kabar? (Asmiati, Wawancara; 69-2016)"

Wawancara tersebut selaras dengan hasil observasi pada tangga 10 September 2016, kepala sekolah sedang berada di ruang guru, beliau berkomunikasi dengan wakil-wakil, guru-guru yang sudah datang tetapi belum masuk waktu mengajar. Hal tersebut mengisyaratkan bahwa sebagai seorang kepala sekolah haruslah memiliki kepribadian yang ramah, supel dan tidak segansegan untuk berkomunikasi dengan bawahan, walaupun sebenarnya jabatan kepala sekolah lebih tinggi dari yang lainnya, sehingga dalam menjalankan tugas tidak akan terasa kaku. Komunikasi harus dibangun dari semua pihak, baik dari atasan ke bawahan, dari bawahan ke atasan, bawahan ke bawahan maupun dari pihak sekolah ke luar sekolah sekalipun.

Seberapapun tinggi tingkat pendidikan dan ilmu yang luas seorang pemimpin sehingga ia mampu menaklukkan tantangan-tantangan, menciptakan ide-ide baru, memiliki jiwa wirausaha, percaya diri, pekerja keras, maupun mengerti manajemen resiko secara jelas, maka akan sulit untuk melangkah lebih jauh jika ia tidak pandai berkomunikasi dan bekerja sama terhadap sesamanya. Karena dengan adanya komunikasi akan lebih mudah dalam mencapai tujuan, dan segala pekerjaan akan terkoordinasi dengan jelas.

Sejalan dengan hal di atas ibu FW. menuturkan bahwa, "Bapak kepala sekolah selalu berkomunikasi dengan bawahan-bawahannya tanpa membedakan ia siapa, bahkan di sekolah ini kami tidak mengganggap orang lain walau memiliki latar belakang keluarga yang berbeda, akan tetapi sudah seperti keluarga, sehingga dalam hal sapa saja menggunakan kata Kakak dan Adik" (Fatmawati, Wawancara; 5-9-2016).

Dari wawancara tersebut memberikan suatu pengertian bahwa dalam hal berkomunikasi kepala sekolah MTs Negeri 1 Palembang, tidak segan-segan untuk berkomunikasi dengan siapapun, beliau berusaha berkomunikasi dengan baik agar tidak adanya miss communication. Bahkan mengganggap semua adalah keluarga akan mempermudah dalam membangun komunikasi secara efektif dibandingkan dengan atasan yang acuh tak acuh, kurang peduli dengan bawahan.

Bapak US menuturkan, "Jika ada guru yang kurang mengerti dengan tugasnya, maka dibolehkan untuk bertanya, akan tetapi terlebih dahulu menghadap bawahan-bawahan yang berhubungan dengan permasalahan tersebut. Misal guru yang tidak mengerti mengenai penetapan kurikulum baru di sekolah, maka guru dipersilahkan mendiskusikannya dengan wakil kurikum, jika masih kurang puas maka boleh bertanya langsung pada kepala sekolah (Saleh, Wawancara; 6-9-2016)."

Hubungan antar rekan kerja biasanya tidak luput dari persaingan, yang umumnya berkaitan erat dengan ketidakpuasan bawahan yang satu terhadap bawahan yang lain dalam menapaki jenjang karier masing-masing. Persaingan itu apabila tidak dikelola secara bijaksana akan merembet menjadi perilaku negatif. Hal tersebut menuntut seorang kepala sekolah untuk mampu membina hubungan kerja, yakni dapat bekerja sama antara satu dengan yang lainnya.

Ketika ditanya mengenai hubungan kerja, ibu FW mengatakan, "Pada saat bapak baru dipindahtugaskan di sekolah MTs Negeri 1 Palembang, bapak berusaha mengenal bawahanbawahannya dengan sangat ramah, tidak merasa angkuh sebagai seorang pemimpin, beliau membuat suatu peraturan untuk bersama melalui musyawarah dan disepakati secara bersama-sama dalam mencapai tujuan sekolah secara optimal (Fatmawati, Wawancara; 5-9-2016).,

Hal itu menggambarkan bahwa bapak kepala sekolah memiliki watak dan kepribadian yang tinggi, tak segan-segan berkomunikasi dengan bawahan untuk membina hubungan kerja dengan baik. Beliau berusaha mengenal dan akrab dengan bawahan sehingga timbul rasa kekeluargaan. Pendekatan yang dilakukan oleh bapak kepala sekolah tidak sama satu dengan yang lainnya. 


\section{Haril Penelitian}

Apakah kepala sekolah pernah memberikan teguran dan sanksi jika ada guru dan staf yang melakukan kesalahan?

Ibu IS mengungkapkan bahwa, "Jika ada bawahan yang melanggar peraturan, langsung dipanggil ke ruang kepala sekolah diberi teguran, nasehat, bimbingan agar tidak mengulanginya di kemudian hari. Tetapi ada kala didiamkan oleh bapak, lalu disampaikan secara umum ketika rapat, namun tanpa menyebutkan identitas seseorang yang melanggar tersebut. Sehingga orang yang merasa akan mengintropeksi diri, tanpa memarahinya di depan umum (Suryani, Wawancara; 6-9-2016)."

Kepala sekolah bersikap tegas terhadap yang menyalahi aturan, memberikan sanksi sehingga menjadi pelajaran bagi yang melanggar ataupun yang tidak melanggar. Dengan begitu tidak akan ada yang merasa iri karena keadilan ditegakkan dengan sebaik-baiknya tanpa memandang yang sudah lama bekerja dan baru bekerja di sekolah tersebut. Jika cara memberi pelajaran dengan cara begitu maka pemimpin akan lebih dihormati dan dan dihargai oleh bawahan.

Lain halnya dengan pemimpin yang langsung memarahi/memaki di depan umum karena kesalahannya akan berdampak negatif terhadap yang perilaku yang bersalah atau bahkan sekolah, akan timbul rasa tidak senang, tidak nyaman, ada yang sampai-sampai menyimpan rasa dendam karena ia merasa harga dirinya direndahkan dan sangat merasa malu. Hal ini juga akan mempengaruhi kinerja organisasi dan memperburuk hubungan kerja antara kepala sekolah dan guru. Sejauh ini melalui pengamatan di MTs Negeri 1 Palembang tidak ada kejadian seperti ini, karena bapak kepala sekolah selalu menyikapi masalah secara bijaksana.

Di lain hari yang lain bapak US mengungkapkan, "Bukan hanya memberi sanksi terhadap yang bersalah, tetapi kepala sekolah juga memberi pujian terhadap anggota organisasi yang berprestasi, karena hal tersebut sangat mempengaruhi baik tidaknya hubungan kerja di sekolah (Saleh, Wawancara; 6-9-2016)."

Leader adalah contoh utama juga halnya dengan kepala sekolah, apakah kepala sekolah memberikan contoh yang baik?
Ibu AS mengatakan bahwa, "Bapak kepala sekolah adalah sosok yang disiplin, datang ke sekolah tepat waktu bahkan guru-guru belum datang beliau sudah datang terlebih dahulu, sehingga saya akan merasa malu jika tidak disiplin karena pemimpin saja disiplin apalagi seharusnya bawahannya meneladani beliau (Asmiati, Wawancara; 5-9-2016)."

Berdasarkan hasil observasi memang benar bapak kepala sekolah telah berada di sekolahan sebelum bel masuk berbunyi. Beliau langsung berkomunikasi dengan guru yang telah hadir lalu melihat-lihat keadaan lingkungan sekolah (berkeliling sejenak), melihat kelas, tanamantanaman yang telah tumbuh dengan hijaunya.

Dalam menjalankan peran sebagai manager bagaimana bapak menjalankannya di sekolah yang banyak ragam orangnya?

Bapak YHD juga mengatakan bahwa, "Saya selalu mengajak guru dan staf agar secara bersama-sama untuk mencapai tujuan pendidikan dan sekolah dan dibuka pintu selebar-lebarnya untuk guru dan staf untuk menyampaikan aspirasi. Tanpa ada masukan dan kritik dari bawahan maka hubungan kerja tidak akan terjalin dengan baik, karena hanya saya yang bertindak. Sesungguhnya perbedaan-perbedaan pemikiran itulah akan membuat suatu suatu keputusan yang baik karena dilakukan secara bersama-sama (Darmansyah, Wawancara; 5-9-2016).

Tentunya kebebasan mengemukakan pendapat akan lebih mempererat hubungan antara kepala sekolah dengan guru dan staf, karena dengan adanya kebebasan memberikan aspirasi menunjukkan bahwa bapak kepala sekolah ingin tugas dan tanggung jawab diemban secara bersamasama, sehingga diperlukan keikutandilan semua pihak dalam mendukung hal-hal yang dapat memajukan sekolah. Bila perlu memberikan masukan supaya lebih berkualitas dalam hal membuat program-program baik di bidang pembelajaran, sarana prasarana, pelayanan dan lainlain.

\section{Peran Kepempimpinan Kepala Madrasah Administrator}

Motivasi menyangkut kompetensi kepala sekolah dalam hubungan antar pribadi yang berkenaan dengan orang lain dan memotivasi 


\section{Hasil Penelition}

mereka agar bersungguh-sungguh dalam mengerjakan tugasnya. Untuk menggerakkan wakil, guru, staf, dan siapapun yang menjadi bagian dari personel sekolah, kepala sekolah tidak boleh membiarkan mereka bergerak dengan sendirisendiri tanpa adanya motivasi baik berupa ucapan, penghargaan maupun perbaikan lingkungan. Semua personel harus didorong dan dirangsang agar mereka melakukan tugasnya dengan semaksimal mungkin diawali dari pemimpinnya dan memotivasi bawahan merupakan kewajiban bagi setiap pemimpin (kepala sekolah).

Ibu HFW mengatakan, "Jika ada siswa yang berprestasi maka diberi hadiah berupa benda walaupun itu hanya berbentuk buku saja. Akan tetapi terhadap guru dalam hal memotivasinya yaitu diberi kepercayaan dengan menggemban tanggung jawab yang lebih tinggi lagi disamping memberi pujian terhadap guru yang berkualitas. Sehingga baik siswa maupun guru akan termotivasi untuk menjadi pribadi yang lebih baik dan lebih baik lagi (Wazier, Wawancara; 5-9-2016)."

Sebenarnya banyak cara untuk membuat motivasi, yaitu selain dari perkataan bagus, baik, benar, senyuman, sapaan, penghargaan dan dapat dengan memperhatikan lingkungan kerja yang diharapkan oleh bawahan-bawahan. Buat ruangan guru, kelas siswa, lingkungan sekolah senyaman mungkin. Bila perlu tanyakan apa yang dibutuhkan guna menunjang bershasilkan proses pembelajaran.

Bapak YDH selaku kepala sekolah MTs Negeri 1 Palembang mengatakan, bahwa dalam mengembangkan sekolah itu harus ada performance (penampilan) dan administrasi yang bagus sehingga meningkatkan prestasi kerja. Sehingga saya sangat memperhatikan lingkungan kerja dengan sebaik mungkin, dalam mengubah lingkungan sekolah menjadi lebih nyaman saya lebih banyak menyumbang dengan pikiran (program kerja) dari pada mengerjakannya sendiri karena faktor usia (Darmansyah, Wawancara; 5-92016).

Ibu FW mengatakan bahwa, "Bukan hanya dari segi ucapan yang diberikan oleh bapak kepala sekolah agar bawahannya semangat untuk bekerja, yakni perbaikan lingkungan sekolah. Ruang guru direhab lebih rapi, ruang kelas dibuat lebih nyaman seperti jendela diperbaiki dan diberi hordeng, meja kursi yang sudah buruk diganti, sehingga tercipta semangat untuk mengajar dan belajar (Fatmawati, Wawancara; 5-9-2016). "

Lingkungan pekerjaan mencakup seluruh sarana prasarana kerja yang ada di sekolah yang mempengaruhi pelaksanaan pekerjaan. Lingkungan ini meliputi ruang kelas, ruang guru, perpustakaan, alat-alat yang berhubungan dengan proses belajar, kebersihan, pencahayaan sangat menunjang berjalannya proses belajar mengajar dengan baik. Jika lingkungan kerja itu kotor, kumuh, pengap akan membuat guru dan siswa malas untuk beraktivitas, walau mereka belajar dan mengajar tetapi akan ada rasa keterpaksaan dan akan cepat merasa jenuh.

Dalam memberikan tugas, bagaiamana sikap kepala sekolah? "Ketika bapak kepala sekolah menyerahkan tugas pada bawahannya beliau tidak terlihat seperti memerintah, tetapi lebih pada mengajak dan menganjurkan. Sehingga guru-guru yang merasa sudah lama mengajar di sini merasa bukan diperintah tetapi diajak bersama-sama untuk mencapai tujuan sekolah", tutur bapak US.

Bahasa yang digunakan oleh kepala sekolah saat menyuruh akan sangat mempengaruhi kualitas dari hasil pekerjaan. Jika guru dan staf diperintah dengan bahasa yang lembut, halus, persuasif, nada yang rendah akan lebih bersemangat untuk mengerjakannya karena merasa dimintai tolong. Lain halnya dengan memerintah dengan nada yang keras, membentak, kasar, dan bahasa yang kurang enak didengar terkesan sangat benarbenar memerintah maka pekerjaan akan dilaksanakan dengan rasa keterpaksaan, pekerjaan terselesaikan guru dan staf akan merasa tertekan dan tidak nyaman. Apalagi jika guru yang sudah lebih lama mengajar disana akan merasa tidak dihargai sehingga membuat kinerjanya menurun.

Motivasi dalam menggerakkan guru dan staf juga hal penting dilakukan, apakah bapak kepala sekolah juga melakukannya?

Menurut Ibu AS, "Bapak kepala sekolah memberi motivasi bawahannya dengan cara keteladanan, beliau memberikan teladan, beliau mengajak menanam tanaman beliau juga ikut serta dalam pengerjaanya, beliau mengajak untuk disiplin waktu, beliau juga datang sebelum bel berbunyi dan pulang setelah bel berbunyi, beliau mengajak untuk menjaga kebersihan, dan beliau 


\section{Haril Penelitian}

juga ikut bersih-bersih lingkungan bahkan pernah beliau melihat ruang WC kotor beliau sendiri yang membersihkannya, tetapi terkadang beliau hanya mengawasi saja ketika beliau telah memberikan contoh dalam pengerjaannya" (Asmiati, Wawancara; 5-9-2016).

Ibu FW juga mengatakan bahwa, "Bapak memotivasi guru dengan cara mengarahkan, mendukung, dan memfasilitasi apa yang menjadi rencana guna pengembangan kualitas mengajar, tapi terkadang juga memberi kebebasan untuk menjalankan programnya agar guru menjadi lebih mandiri tetapi tetap di bawah pengawasan bapak (Fatmawati, Wawancara; 5-9-2016).”

Kepala sekolah yang memberikan keteladanan dan pengawasaan terhadap tugas-tugas yang diberikan pada guru akan sangat memotivasi agar mengerjakannya dengan penuh kesadaran akan tanggung jawabnya dan terus meningkatkan volume kualitasnya karena nantinya akan ada penilaian dari pemimpin sukses atau tidaknya pelaksaan program yang diajukan tersebut. Kemampuan memotivasi kepala sekolah sangat mempengaruhi bersedia tidaknya guru dan staf untuk terus meningkatkan kesadaran dirinya untuk kemajuan sekolah.

Sebagai top leader disekolah ini, dalam menjelankan program sekolah, siapa saja yang akan bapak libatkan, apa ada alansan tertentu?

Bapak YHD mengatakan, "Ketika saya memiliki program kerja, maka saya ikut terjun langsung dalam pengerjaannya atau setidaknya mengawasi, sehingga secara tidak langsung saya telah membina staf saya, saya memerintahkan staf saya agar tepat waktu datang ke sekolah dan saya harus melakukannya terlebih dahulu, dan sebenarnya guru-guru di MTs Negeri 1 Palembang ini sudah membutuhkan guru-guru yang lebih muda dan memiliki pendidikan minimal S2 karena akan lebih mudah mencapai tujuan sekolah, mereka memiliki semangat yang lebih tinggi (Darmansyah, Wawancara; 5-9-2016)."

Memang menjadi kepala sekolah tidak bisa hanya sekedar berpikir dan bergulat dengan wacana sembari memerintah bawahannya untuk mengerjakan perintahnya, melainkan kepala sekolah juga dituntut untuk bekerja keras mengurus sendiri persoalan-persoalan sekolah. Memang betul bahwa bawahan bertugas untuk membantu meringankan beban atasannya, akan tetapi tidak serta-merta semua tugas harus diserahkan kepada bawahan. Suatu pekerjaan yang memang menjadi tugas seseorang dan dia mampu melakukannya, maka janganlah pekerjaan itu diserahkan kepada orang lain. Dengan mengerjakan sesuatu yang masih mampu dikerjakan sendiri memberi teladan kepada bawahan dan juga membina bawahan secara tidak langsung.

Bagaimana dengan tanggung jawab sebagai peminpin disekolah ini? Pernyataan ibu AS ini memperkuat apa yang telah disampaikan oleh bapak kepala sekolah, bahwa bapak itu orangnya sangat bijak dan sangat bertanggung jawab, sehingga beliau selalu berusaha memperbaiki sekolah, mengajak bersama-sama, mengawasi pelaksanaannya, dan selalu membicarakan kepada yang lain, misalnya besok kita akan membeli pot untuk penghijauan. Sepertinya bapak bermaksud membina guru dan staf agar bermusyawarah untuk semua urusan, berkomunikasi, ujar ibu Asmiati (Asmiati, Wawancara; 5-9-2016).

Jika dilihat dari pernyataan di atas bapak kepala sekolah selalu memberikan penjelasan, memberikan contoh tentang apa yang ditugaskannya, menunjukkan bahwa beliau tidak mau dianggap orang yang hanya memberikan perintah namun aplikasi terhadap diri sendiri tidak ada. Keteladanan sangat cocok dalam membina bawahan-bawahan agar lebih mengembangkan kompetensi dan kariernya. Tentunya hal tersebut juga meminimalisir terjadinya kekeliruan dalam pengerjaannya.

Ketika ditanya (Sebagai penggerak, bagaimana kepala sekolah menjalankannya, berikan contoh singkat?) dengan ibu IS, beliau mengatakan, "Memang benar bapak kepala sekolah ketika memerintahkan untuk membuat penghijauan sekolah, beliau terjun langsung untuk mengerjakannya mengajak siswa, guru yang belum waktu mengajar, beliau memberi contoh lalu mengerjakannya secara bersama-sama (Suryani, Wawancara; 6-9-2016)."

Sebagai seorang pemimpin dalam lingkup sekolah tentunya kepala sekolah tidak mau dikatakan seperti dalam bahasa jawa yakni meminjam istilah pondok "jarkoni (ngajar ora ngelakoni)" yang maksudnya orang yang selalu memerintahkan orang lain untuk mengerjakan yang baik tetapi ia sendiri tidak melakukannya atau 


\section{Hagil Penelition}

bahkan melanggarnya, sehingga orang yang seperti itu tidak patut dijadikan seorang pemimpin.

Dan ternyata buka hanya keteladan yang diberikan oleh bapak kepala sekolah, tetapi membina skill melalui seminar seperti yang diungkapkan oleh bapak Usman Saleh bahwa, "Bapak kepala sekolah memberikan pengarahan terlebih dahulu, jika ada staf yang belum paham dengan tugasnya maka diberi penjelasan secara detail. Seminar sangat perlu diberikan kepada guru sesuai dengan bidangnya (Saleh, Wawancara; 6-92016)."

Ibu FW juga menegaskan bahwa, "Bapak kepala sekolah memberi saran kepada para guru untuk selalu bertanya dan berdiskusi pada guruguru yang mengajar mata pelajaran yang sejenis guna bertukar pikiran yang dapat memperluas pengetahuan dan dapat mengatasi kesulitankesulitan yang sedang atau mungkin akan dihadapi (Fatmawati, Wawancara; 5-9-2016)."

Berdiskusi dengan guru yang mengajar bidang study yang sama akan sangat efektif dalam mengembangkan kemampuan seorang guru, karena pada hakikatnya setiap individu pasti dihadapkan dengan yang namanya masalah walau masalah yang bersifat besar atau kecil, sulit atau tidak sulit, tentunya harus ada penyelesaian, kita tidak mungkin hidup tanpa masalah, dan adanya masalah yang menghampiri kita akan membina kita agar memiliki pemikiran terbuka dan selalu ingin belajar walaupun pada seseorang tersebut telah menjadi guru/pendidik.

\section{Dampak Peran Kepempimpinan Kepala Madrasah dalam Mengembangkan Budaya Membaca al-Qur'an di MTs Negeri 1 Palembang}

Perilaku bawahan tersebut mempengaruhi kepemimpinan kepala sekolah untuk menjadi efektif atau tidak. Bawahan yang aktivitasnya tinggi, pengetahuannya tinggi, cenderung lebih aktif akan membuat kepala sekolah untuk menerapkan gaya kepemimpinan yang demokratis, memberi kesempatan kepada bawahan untuk berkreasi dan tidak terlalu mencampurinya karena sifat mereka tidak ingin selalu diperintah, lain halnya dengan bawahan-bawahan yang pasif, aktivitasnya rendah dan terbiasa diperintah dan diterapkan dengan gaya yang otoriter, maka tidak akan cocok jika diterapkan dengan gaya demokratis, sehingga kepala sekolah dituntut untuk mampu menyesuaikan dengan karakteristik bawahan yang ia pimpin.

Ibu IS mengatakan bahwa, "Guru-guru disini ada yang cenderung ingin diperintah, walaupun ada yang tidak diperintah mereka telah mengerjakan sendiri, hanya sedikit dari mereka yang memiliki ide-ide untuk kemajuan sekolah, sehingga kepala sekolah selalu menyesuaikan diri dengan bawahannya" (Suryani, Wawancara; 6-92016).

Kepala sekolah akan berhasil dengan baik dalam menjalankan tugasnya, apabila setiap pemimpin memahami setiap tugas yang harus dilaksanakannya. Kepemimpinan akan tampak dalam proses dimana seseorang mengarahkan, membimbing, mempengaruhi dan atau menguasai pikiran-pikiran, perasaan-perasaan atau tingkah laku orang lain/bawahan-bawahannya. Disamping itu kepala sekolah harus menjalin hubungan kerjasama yang baik dengan bawahan, sehingga terciptanya suasana kerja yang membuat bawahan merasa, nyaman, aman, tentram, dan memiliki suatu kebebasan dalam mengembangkan ide dan kompetensinya dalam rangka tercapai tujuan sekolah yang telah ditetapkan.

Dari hasil observasi bapak kepala sekolah tidak mencampuri urusan bawahan yang bukan wewenangnya, kepala sekolah memberikan kepercayaan kepada bawahannya bahwa bawahan memiliki kemampuan untuk melaksanakan tugas dan kewajibannya semaksimal mungkin.

Seseorang dengan menerima tuntutan tugas yang tinggi akan dapat menimbulkan kemauan yang keras untuk mau mengerjakan suatu kegiatan yang menjadi kewajibannya dan bahkan tidak segan-segan melaksanakan tugas di luar perannya.

Bapak US mengatakan bahwa, "Dalam hal pemberian tugas, bapak kepala sekolah langsung memerintahkan kepada bawahannya, di bidang kurikulum kepada ibu Ros, sehingga jika ada guru yang belum mengerti, bertanya kepada ibu Ros, siswa bermasalah kepada guru Bk, dan lain-lain, jadi tugas diserahkan pada yang ahlinya, jika tugas itu menyangkut untuk umum maka dirapatkan terlebih dahulu. Namun jika ada yang belum puas boleh saja menghadap bapak kepala sekolah 


\section{Haril Penelitian}

dengan tata cara prosedur yang ada" (Saleh, Wawancara; 6-9-2016).

Beragamnya tugas menuntut kemampuan kepala sekolah dalam memilah-milah mana tugas yang harus diberikan kepada individu, membutuhkan pengerjaan secara kelompok. Bukan hanya dilihat dari segi tugasnya saja, akan tetapi dari pribadinya juga perlu diperhatikan, ada bawahan yang menyukai kerja mandiri sehingga hanya membutuhkan pengarahan terhadap tugasnya ada juga yang lebih menyukai kerja secara kelompok sehingga pemimpin harus mengarahkan dan membimbing secara telaten.

Bila dikaitkan dengan program tahfidz alQur'an yang sudah dijalankan di MTs Negeri 1 Palembang berikut pendapat narasumber di bawah ini:

Selama berjalannya program tahfidz di MTs ini, banyak sudah kemajuan yang terlihat, misalnya saja dari dari yang tadinya siswa baru belum bisa ataupun belum lancar membaca alQur'an alhamdulillah sekarang sudah lancar bahkan ada di antaranya yang sudah mengikuti program tahfidz. Selain itu yang lebih membanggakan adalah banyak di antara murid peserta tahfidz sudah hafal lebih dari 5 juz dan 7 juz. Yaaa kalau yang 1 juz sudah lumrah (Darmansyah, Wawancara; 5-9-2016).

Ketika peran kepala sekolah sudah berjalan maksimal, dampak apa yang paling mudah terlihat?

Bapak US menjelaskan bahwa, "Setiap sekolah pasti memiliki budaya untuk sekolahnya masing-masing, dan semuanya berusaha untuk mentaati peraturan yang ada di sekolah, yang mana budaya sekolah ini dibuat bukan hanya oleh kepala sekolah tetapi melibatkan bawahanbahwahannya dan budaya mengasumsikan kehidupan yang berjalan natural, tidak lagi dirasakan sebagai beban (Saleh, Wawancara; 6-92016).”

Dari keterangan yang disampaikan oleh bapak kepala sekolah di atas dapat diketahui bahwa kepala sekolah berperang pro aktif dalam program budaya membaca al-Qur'an yang dikembangkan di MTs N 1 Palembang ini. Hal ini tentu saja berdampak pada tercapainya budaya membaca alQur'an di MTs N 1 Palembang dibuktikan dengan sudah banyak siswa yang hafal 1 juz bahkan ada yang 5 dan 7 juz. Selain keterangan dari kepala sekolah di atas berikut juga dijelaskan mengenai dampak peran aktif kepala madrasah dalam program budaya membaca al-Qur'an:

Alhamdulillah, dengan adanya program membaca al-Qur'an semua murid di MTs ini terjadwal membaca al-Qur'an, bahkan saya dan teman-teman bisa mengahafal al-Qur'an dengan bimbingan guru-guru. Di antara teman-teman juga ada yang sudah hafal 2,3,4,5, bahkan 7 juz. Kalau 1 juz sudah rata hafal. Selain itu juga kepala sekolah sudah mengawasi langsung proses setoran hafalan, dan juga terkadang memberikan hadiah kepada murid yang dia nggap bagus hafalannya, misalnya dengan memberikan al-Qur'an baru (Ulhaq, Wawancara; 7-9-2016).

Kepala sekolah menentukan budaya sekolah melalui rapat bersama sehingga disepakati secara bersama-sama dan dijalankan oleh orangorang yang berada di lingkup sekolah tanpa terkecuali. Semua personel sekolah memiliki kewajiban untuk menjaga dan memelihara budaya sekolah. Untuk terlaksananya iklim sekolah, kepala sekolah akan memberi teladan kepada bawahannya, sehingga budaya sekolah tersebut benar-benar diterapkan bagi semua pihak dalam organisasi sekolah.

Dalam hal mendidik anak diperlukan budaya toleransi agar anak terbiasa untuk menghormati dirinya sendiri atau orang lain yang beda agama, budaya, ras, bahasa ataupun daerah. Adanya motivasi berupa dorongan, pujian, dukungan juga sangat diperlukan bagi siswa supaya ia lebih percaya diri terhadap kemampuannya sehingga ia dapat mengoptimalkan untuk meraih masa depannya dan ia akan lebih menghargai dirinya sendiri. Rasa kasih sayang, persahabatan dan perlakuan yang baik dalam mendidik akan berpengaruh terhadap siswa untuk lebih mencintai sesama tanpa membeda-bedakannya sehingga ia akan lebih tertanam di dalam dirinya untuk selalu berbuat adil. Siswa juga tidak akan mencurigai orang lain tanpa sebab, ia selalu berpikir positif terhadap terlebih nanti ia sudah besar menjadi pemimpin ia akan memberikan kepercayaan kepada bawahan-bawahannya bahwa bawahan memiliki kemauan dan kemampuan untuk tugas dan tanggung jawabnya jika ia dididik dengan memberikan rasa aman. 


\section{Haril Penelitian}

"Kepala sekolah, guru, TU, siswa dan semua personel sekolah yang melanggar aturan dan kebijakan-kebijakan sekolah mendapatkan sanksi baik berupa teguran dan hukuman, hal ini bertujuan agar budaya sekolah benar-benar ditaati karena terkadang budaya sekolah yang satu dengan sekolah lainnya berbeda, sehingga hal ini menjadi ciri khas bagi sekolah kita" (Wazier, Wawancara; 5-9-2016).

Dalam membangun budaya sekolah kita harus berperan menjadi sosok dari budaya yang akan direalisasikan, kepala sekolah diharapkan mampu membantu bawahan untuk menciptakan rasa memiliki jati diri, mampu mengembangkan rasa kekeluargaan, rasa memiliki terhadap sekolah akan membuat semua pihak akan berjuang dengan sekuat tenaga agar tercapainya tujuan sekolah. Seorang pemimpin juga diharapkan mampu menjadi teladan, sebagai hasil dari norma-norma perilaku yang telah disepakati bersama. Sekolah merupakan masyarakat dalam lingkup kecil adanya kepala sekolah, guru, siswa, staf, satpam dan lainlain sebagai anggota masyarakat. Memiliki peran, tugas, kewajiban masing-masing, semua saling membutuhkan, saling tolong menolong, dan pastinya akan timbul rasa saling memiliki menuju pada tujuan yang sama.

\section{Kesimpulan}

Peran kepempimpinan kepala madrasah dalam mengembangkan budaya membaca al-Qur'an di MTs Negeri 1 Palembang terlihat pada Kemampuan melakukan koordinasi pada kegiatan tahfidz al-Qur'an, dalam hal penyelesaian masalah dalam program tahfidz al-Qur'an, beliau memberikan wewenang kepada yang bersangkutan untuk menyelesaikannya. Kepala sekolah membangun komunikasi dengan bahasa yang baik terutama pada masalah dalam yang menyangkut kegiatan tahfidz. Kepala sekolah telah memberikan motivasi baik pada peserta tahfidz mauapun guru yang bertugas, baik berbentuk pujian, kepercayaan dan berbentuk fisik.

Dampak peran kepempimpinan kepala madrasah dalam mengembangkan budaya membaca al-Qur'an di MTs Negeri 1 Palembang menjadikan program budaya membaca al-Qur'an yang terfokus pada kegiatan budaya membaca al-Qur'an (melalui program tahfidz al-Qur'an) di MTs N 1 Palembang berjalan efektif terbukti dengan banyak siswa yang sudah hafal 1 juz bahkan ada yang 5 dan 7 juz.

\section{Daftar Pustaka}

Amrullah, Fahmi. Ilmu Al-Qur'an untuk Pemula. Jakarta: Artha Rivera. 2008.

Amtu, Onisimus. Manajemen Pendidikan di Era Otonomi Daerah. Bandung: Alfabeta. 2011.

Arikunto, Suahrsimi. Metode Penelitian Kualitatif. Jakarta: Grafika Media. 2007.

Arikunto, Suharsimi. Prosedur Penelitian (Suatu Pendekatan Praktik). Jakarta: Rineka Cipta. 2011.

Djamarah, Saiful. Psikologi Belajar. Jakarta: Rineka Cipta. 2008.

Fattah, Nanang. Landasan Manajemen Pendidikan. Bandung: PT. Remaja Rosdakarya. 2004.

Fitri dkk. Manajemen Berbasis Sekolah. Palembang: Rafah Press. 2011.

Hawi, Akmal. Kompetensi Guru Pendidikan Agama Islam. Palembang: IAIN Raden Fatah Press. 2004.

Hermino, Agustinus. Assesmen Kebutuhan Organisasi Persekolahan. Jakarta: P.T Gramedia. 2013.

Hikmat. Manajemen Pendidikan. Bandung: Pustaka Setia. 2011.

Idi, Abdullah. Sosiologi Pendidikan. Jakarta: P.T Raja Grifindo Persada. 2013.

Madjid, Nurkolis. Manajemen Berbasis Sekolah Teori, Model dan Aplikasi. Jakarta: Grasindo. 2003.

Mas'ud dan Kurnurdilo. Manajemen Pondok Pesantren. Jakarta: Diva Pustaka. 2005.

Moleong, Lexy. Metodologi Penelitian Kualitatif . Bandung : P.T Remaja Rosda Karya. 2014.

Mufham, Al-Amin. Manajemen Pengawasan. Jakarta: P.T Gramedia. 2006.

Mulyasa. Menjadi Kepala Sekolah Profesion al. Bandung: Remaja Rosdakarya. 2004.

Purwanto. Evaluasi Hasil Belajar. Jogjakarta: Pustaka Belajar. 2013.

Qomar, Mujammil. Manajemen Pendidikan Islam. Malang: Erlangga. 2007.

Ris'an Dkk. Panduan Penulisan Karya Ilmiah, Palembang:Program Pascasarajan IAIN Raden Fatah. 2012. 


\section{Hagil Penelition}

Samsul, Nizar. Lembaga Pendidikan Islam. Jakarta: Raja Grafindo. 2008.

Sudjono, Anas. Pengantar Statistik Pendidikan. Jakarta: PT. Raja Grafindo Persada. 2009.
Sugiyono. Metode Penelitian Kuantitaif, Kualitatif dan R\&D. Bandung: ALFABETA. 2013. 